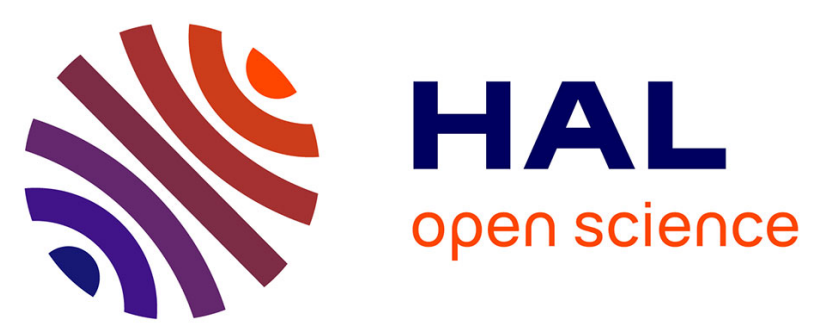

\title{
Defects in the CD19 complex predispose to glomerulonephritis, as well as IgG1 subclass deficiency
} Nicolas Vince, David Boutboul, Gael Mouillot, Nicolas Just, Maria Peralta, Jean-Laurent Casanova, Mary Ellen Conley, Jean-Christophe Bories, Eric Oksenhendler, Marion Malphettes, et al.

\section{To cite this version:}

Nicolas Vince, David Boutboul, Gael Mouillot, Nicolas Just, Maria Peralta, et al.. Defects in the CD19 complex predispose to glomerulonephritis, as well as IgG1 subclass deficiency. Journal of Allergy and Clinical Immunology, 2011, 127 (2), pp.535-538.e2. 10.1016/j.jaci.2010.10.019 hal-02131526

\author{
HAL Id: hal-02131526 \\ https://hal.science/hal-02131526
}

Submitted on 20 May 2019

HAL is a multi-disciplinary open access archive for the deposit and dissemination of scientific research documents, whether they are published or not. The documents may come from teaching and research institutions in France or abroad, or from public or private research centers.
L'archive ouverte pluridisciplinaire HAL, est destinée au dépôt et à la diffusion de documents scientifiques de niveau recherche, publiés ou non, émanant des établissements d'enseignement et de recherche français ou étrangers, des laboratoires publics ou privés. 
1 TITLE PAGE

2

3 Letter to the Editor

4

5

6

Defects in the CD19 complex predispose to glomerulonephritis as well as IgG1 subclass deficiency.

7

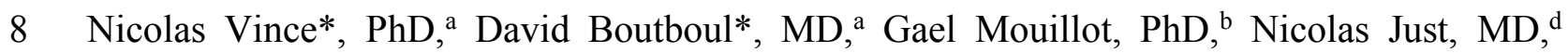

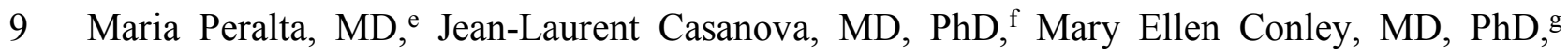

10 Jean-Christophe Bories, $\mathrm{PhD},{ }^{\mathrm{a}}$ Eric Oksenhendler, $\mathrm{MD},{ }^{\mathrm{a}, \mathrm{c}}$ Marion Malphettes*, MD, ${ }^{\mathrm{a}, \mathrm{c}}$ Claire

11 Fieschi*, MD, PhD; ; c and the DEFI Study Group**.

12

$13 *$ These authors contributed equally to this work

$14 * *$ Listed in the appendix

15

16 a. EA3963, Université Paris 7 Denis Diderot, centre Hayem, Hôpital Saint-Louis, 1 avenue

17 Claude Vellefaux 75010 PARIS France

b. Laboratoire d'Immunologie Cellulaire et Tissulaire, Hôpital Pitié Salpêtrière et INSERM UMR-S945, Bâtiment CERVI, Paris, France

c. Département d'Immunologie Clinique, Hôpital Saint-Louis, AP-HP, 1 avenue Claude

21 Vellefaux 75010 PARIS France

22 d. Département de Pneumo-Allergologie, $\mathrm{CH}$ Roubaix, 35 rue de Barbieux 59056 Roubaix 23 France

e. CH Mulhouse, 87 avenue d'Altkirch 68051 Mulhouse 
25 f. Unité d'immunologie et d'hématologie, Hôpital Necker, AP-HP, 149 rue de Sèvres 75015 26 PARIS France

27 g. University of Tennessee and St Jude Children's Research Hospital, Memphis, Tenn., USA

29 Corresponding author

30 Claire Fieschi, MD, PhD

31 Département d'Immunologie Clinique

32 Hôpital Saint-Louis, AP-HP

331 avenue Claude Vellefaux

3475010 PARIS France

35

36 Telephone: +33142499690

$37 \quad$ Fax: +33142499472

38 E-mail: claire.fieschi@sls.aphp.fr

40 This work was supported by grants from Programme Hospitalier de Recherche Clinique 2005

41 (Eric Oksenhendler), GIS maladies rares (Eric Oksenhendler), ANR MRAR-06 (Claire 42 Fieschi), Fondation pour la recherche Médicale (Claire Fieschi). Nicolas Vince was supported 43 by La Ligue Nationale Contre le Cancer. David BOUTBOUL was supported by Le Fonds 44 d'Etude et de Recherche du Corps Medical and SHIRE.

45

46 Word count: 995 


\section{Capsule Summary}

48 We identified two novel mutations in CD19. These cases add to the clinical and biological 49 phenotype of CD19 deficiency and point to CD19 possible role in IgG1 switching and control 50 of autoimmunity

\section{$52 \quad$ Key words}

53 CVID, IgG1 subclass deficiency, glomerulonephritis, auto-immunity, CD19 deficiency 


\section{To the Editor:}

Common variable immunodeficiency (CVID) and selective IgG1 deficiency are primary immunodeficiencies characterized by defective antibody production leading to recurrent infections of the respiratory tract ${ }^{1-3}$. Recent studies have identified $C D 19$ and $C D 81$ biallelic mutations as underlying CVID in humans. On mature B cells, CD19 functions in a complex with CD21, CD81, and CD225 and acts synergistically with the B cell antigen receptor to induce activation and maturation of the activated $\mathrm{B}$ cells into the memory compartment ${ }^{4}$.

Only five patients with bi-allelic deleterious mutations in CD19 have been described to date ${ }^{5-}$ 7. Despite variability in CD19 expression, these patients display a remarkable similar phenotype characterized by moderately severe hypogammaglobulinemia, impaired antibody responses upon vaccination and impaired memory B cell formation. We report on two additional patients with CD19 deficiency from two different families.

Out of 400 patients from the French national DEFI cohort with primary hypogammaglobulinemia, 18 had CD19+ cells $<1 \%$ but a percentage of T, NK and CD19 B cells that didn't add up to $100 \%$. Double CD19/CD20 staining performed in these 18 patients demonstrated a CD19 defect in two patients (Figure E1).

Patient A, a girl of Kurdish descent was referred at 11 years of age with pneumococcal meningitis. She also had a history of recurrent upper respiratory tract infections and giardiasis starting in early childhood. She was found to have hypogammaglobulinemia and impaired antibody response to vaccination (Table E1). Patient B, a girl of Moroccan descent and the second child of consanguineous parents was first referred at 13 years of age with failure to thrive. Urinalysis revealed microscopic hematuria and proteinuria without renal failure. Tests for antinuclear antibodies were positive $($ titer $=1 / 640)$ in the absence of anti-DNA and antiENA antibodies. The complement levels were normal. At 27 years of age, she had surgery for chronic sinusitis and at 29 years of age she developed pneumococcal pneumonia. She was 
found to have selective IgG1 deficiency (Table E1). Antibodies to polio and tetanus toxin were detected at protective levels and antibodies to pertussis toxin were detectable albeit at a low level. Isohemaglutinins were present. At 31 years of age, she was referred with nephrotic syndrome and end stage renal disease. A renal biopsy revealed endo-capillary proliferative glomerulonephritis with intense mesangial $\operatorname{IgA}$ deposits associated with diffuse interstitial fibrosis consistent with a diagnosis of IgA nephropathy.

CD19 genomic sequencing showed homozygous deletion (1464delC) causing a premature stop codon (P488PfsX15) in patient A. Patient A's parents and brother were heterozygous for the mutated allele. Patient B, born to consanguineous parents, was found to have an insertion (1653_1671+9del28pbins23pb), assumed to be homozygous and disrupting the wild type stop codon (G551GfsX25). Her two children were heterozygous for the mutated allele. Both mutations were frameshift mutations located in the intracytoplasmic domain of CD19, as seen in previously reported patients ${ }^{5,6}$ (Figure 1). Normal levels of CD19 transcripts were found by quantitative RT-PCR in patients EBV transformed cell lines (data not shown). Absence of CD19 protein has been confirmed by western blot on these cell lines (Figure E2). However, Western blotting on EBV lines may not be sufficient to prove that the mutation is null in all B cells. Actually, a minority of B cells from patient B expressed CD19, but these cells are not present in EBV transformed cells (Figure E1). One could guess that there are a small number of cells in which alternative stop codons are used and we cannot rule out that this could account for the distinct phenotype.

Patient $A$ had normal B cell count but a sharp reduction in IgD-CD27+ switched memory B cells while IgD+CD27- naive B cells were increased (both in percentage and absolute count). Patient B displayed a slight reduction of B cell population. Within the B cell compartment, the relative frequency of $\operatorname{IgD}-\mathrm{CD} 27+$ switched memory and $\operatorname{IgD}+\mathrm{D} 27-$ naive $\mathrm{B}$ cells was normal (Table E2 and Figure E1). Flow-cytometric immunophenotyping revealed low CD19 
104 expression in all five carriers. Levels of CD21 were decreased whereas levels of CD81 were

105 normal on B cells from both patients and carriers (Figure E1). Proliferation of purified total

106 and naive B cells from both patients was studied after stimulation with anti-IgM antibody,

107 anti-CD40+IL10 or CpG and showed proliferation comparable to controls (Figure 2a). In

108 vitro Ig production showed very low IgG production by purified total and naive B cells after

109 stimulation with anti-CD40+IL10 or CpG, whereas IgM production was similar to a control

110 for both patients (Figure 2b).

111 Considering the high similarity among patients exhibiting a monogenic defect in CD19 or

$112 C D 81$, it has been proposed to regard CD19 complex deficiencies as a separate disease within

113 the group of antibody deficiency syndromes ${ }^{7}$. The present study reveals the wide variance

114 among patients with similar CD19 deficiency. Patient $B$ is the first patient with CD19

115 deficiency, selective IgG1 deficiency, conserved antibody response against protein antigens

116 upon vaccination and a normal IgD-CD27+ switched memory B cell compartment. Her

117 immunological phenotype points to a possible role of CD19 in IgG1 switching in humans.

118 Although clinical immune deficiency was present, the major complication in patient B was a

119 severe IgA nephropathy. Interestingly, glomerulonephritis has been observed in two other

120 patients with CD19 complex deficiency (CD19, CD81) ${ }^{6,7}$. The high frequency of

121 nephropathy in 3 out of 8 patients with CD19 complex deficiency is striking. It has been

122 recently reported that $\mathrm{CD} 19^{-/-}$lupus prone NZB/W mice lack a potent splenic regulatory B

123 cell subset (B10 cells) producing IL10, which could account for the significantly earlier onset

124 of nephritis in these knock-out mice when compared with wild type NZB/W controls ${ }^{8}$.

125 In conclusion, we describe 2 new cases of CD19 deficiency in patients with antibody 126 production defect. In such patients, lymphocyte phenotyping with an anti-CD19 antibody can

127 lead to a false diagnosis of B cell alymphocytosis. In order to avoid misdiagnosis in that 128 context, immunophenotypes using CD19 staining should be carefully examined to detect a 
129 gap due to unstained B lymphocytes in all patients with immunoglobulin production defect,

130 including IgG sub-class deficiencies.

132 Nicolas Vince*, MSc, ${ }^{\mathrm{a}}$

133 David Boutboul*, MD, ${ }^{\mathrm{a}}$

134 Gael Mouillot, $\mathrm{PhD},{ }^{\mathrm{b}}$

135 Nicolas Just, MD, ${ }^{\mathrm{d}}$

136 Maria Peralta, MD, ${ }^{\mathrm{e}}$

137 Jean-Laurent Casanova, $\mathrm{MD}, \mathrm{PhD},{ }^{\mathrm{f}}$

138 Mary Ellen Conley, $\mathrm{MD}, \mathrm{PhD},^{\mathrm{g}}$

139 Jean-Christophe Bories, $\mathrm{PhD},{ }^{\mathrm{a}}$

140 Eric Oksenhendler, MD, ${ }^{\mathrm{a}, \mathrm{c}}$

141 Marion Malphettes*, MD, ${ }^{\text {a, c }}$

142 Claire Fieschi*, MD, PhD; ; , c

143 and the DEFI Study Group.

144

$145 *$ These authors contributed equally to this work

146

147 a. EA3963, Université Paris 7 Denis Diderot, centre Hayem, Hôpital Saint-Louis, 1 avenue 148 Claude Vellefaux 75010 PARIS France

149 b. Laboratoire d'Immunologie Cellulaire et Tissulaire, Hôpital Pitié Salpêtrière et INSERM

150 UMR-S945, Bâtiment CERVI, Paris, France

151 c. Département d'Immunologie Clinique, Hôpital Saint-Louis, AP-HP, 1 avenue Claude 152 Vellefaux 75010 PARIS France 
153 d. Département de Pneumo-Allergologie, $\mathrm{CH}$ Roubaix, 35 rue de Barbieux 59056 Roubaix 154 France

155 e. $\mathrm{CH}$ Mulhouse, 87 avenue d'Altkirch 68051 Mulhouse

156 f. Unité d'immunologie et d'hématologie pédiatrique, Hôpital Necker, AP-HP, 149 rue de

157 Sèvres 75015 PARIS France

158 g. University of Tennessee and St Jude Children's Research Hospital, Memphis, Tenn., USA 


\section{Aknowledgments}

We thank Pr Brouet for helpful discussions, as well as critical reading and correction of the manuscript. We thank Dr Aucouturier, Dr Bengoufa and Dr Carmagnat for performing Ig dosage and routine immunophenotyping.

\section{APPENDIX: DEFI study group}

Coordination: E. Oksenhendler, Hôpital Saint Louis, Paris

Clinical Centers: Hôpital Saint Louis, Paris: C. Fieschi, M. Malphettes, L. Galicier, JP Fermand, B. Asli, B. Arnulf, L. Karlin. Bordeaux: JF. Viallard. Limoges: A. Jaccard. Tours: C. Hoarau, Y. Lebranchu. Hôpital Cochin, Paris: L. Mouthon, A. Bérezné. Marseille: N. Schleinitz. Lyon Sud: I. Durieu. Hôpital Necker, Paris: F. Suarez. Clermont-Ferrand: V. Chanet-Porte, M. André, O. Aumaitre. Montpellier: V. Le-Moing. Roubaix: N. Just. Reims: R. Jaussaud. Le Mans: F. Goupil. Lille: E. Hachulla. Perpignan: L. Sanhes. Angers: M. Gardembas, I. Pellier. Lyon Armée: M. Pavic. Dijon: B. Bonnotte. Pitié-Salpêtrière, Paris: J. Haroche, Z. Amoura, G. Leroux. Toulouse: L. Alric. MF. Thiercelin. L. Tetu. D. Adoue. Nancy: P. Bordigoni. Lyon Croix Rousse: T. Perpoint. Lyon Hotel-Dieu: P. Sève. Besançon: P. Rohrlich, F. Legrand. Strasbourg: T. Martin, P. Soulas-Sprauel. Hôpital Foch, Suresnes: LJ. Couderc. Kremlin-Bicêtre: F. Chaix. Hôpital Trousseau, Paris: J. Donadieu, G. Leverger. Rouen: F. Tron, S. Jacquot. Bobigny: C. Larroche. Nantes: A. Masseau, M. Hamidou, C. Thomas. Nancy: M. Morisset. Poitiers: F. Millot. Bondy: O. Fain. Hôpital Bichat, Paris: R. Borie. Rennes: A. Perlat. Clamart: V. Martinez. Hôpital Robert Debré, Paris: T. Leblanc. Labs

Pitié-Salpêtrière, INSERM UMR-S945, Paris: P. Debré, G. Mouillot, JL. Garnier. Saint-Louis, Paris, Immunology and HLA: C. Rabian, M. Carmagnat. Saint-Louis, EA 3963, Paris: C. Fieschi, M. Malphettes, N. Vince, D. Boutboul. Data Management and Statistics: L. Gérard. 


\section{References}

188 1. Geha RS, Notarangelo LD, Casanova JL, Chapel H, Conley ME, Fischer A, et al. Primary immunodeficiency diseases: an update from the International Union of Immunological Societies Primary Immunodeficiency Diseases Classification Committee. J Allergy Clin Immunol 2007; 120:776-94.

192 2. Lacombe C, Aucouturier P, Preud'homme JL. Selective IgG1 deficiency. Clin 193 Immunol Immunopathol 1997; 84:194-201.

194 3. Oksenhendler E, Gerard L, Fieschi C, Malphettes M, Mouillot G, Jaussaud R, et al. Infections in 252 patients with common variable immunodeficiency. Clin Infect Dis $2008 ; 46: 1547-54$.

197 4. Bradbury LE, Kansas GS, Levy S, Evans RL, Tedder TF. The CD19/CD21 signal transducing complex of human B lymphocytes includes the target of antiproliferative antibody-1 and Leu-13 molecules. J Immunol 1992; 149:2841-50.

5. Kanegane H, Agematsu K, Futatani T, Sira MM, Suga K, Sekiguchi T, et al. Novel mutations in a Japanese patient with CD19 deficiency. Genes Immun 2007; 8:663-70.

6. van Zelm MC, Reisli I, van der Burg M, Castano D, van Noesel CJ, van Tol MJ, et al. An antibody-deficiency syndrome due to mutations in the CD19 gene. N Engl J Med $2006 ; 354: 1901-12$.

7. van Zelm MC, Smet J, Adams B, Mascart F, Schandene L, Janssen F, et al. CD81 gene defect in humans disrupts CD19 complex formation and leads to antibody deficiency. J Clin Invest 2010; 120:1265-74.

208 8. Watanabe R, Ishiura N, Nakashima H, Kuwano Y, Okochi H, Tamaki K, et al. 209 Regulatory B cells (B10 cells) have a suppressive role in murine lupus: CD19 and B10 cell deficiency exacerbates systemic autoimmunity. J Immunol 2010; 184:4801-9. 
211 9. Mouillot G, Carmagnat M, Gerard L, Garnier JL, Fieschi C, Vince N, et al. B-Cell and

212 T-Cell Phenotypes in CVID Patients Correlate with the Clinical Phenotype of the Disease. J 213 Clin Immunol 2010; Published online. 


\section{Figure Legends}

215 Figure 1. (a) Schematic representation of the CD19 coding region (14 exons, 1671

216 nucleotides). The new mutations are shown on the top, the known mutations on the bottom.

217 (TM: transmembrane domain). (b) Pedigrees of patients A and B (homozygous are in black, 218 heterozygous are in half black)

220 Figure 2. Proliferation (a) and immunoglobulin production (b) of B cells from both patients

221 and one control, these experiments were also performed on naive B cells and provided 222 comparable results (Data not shown). These results are expressed as the mean of triplicate 223 experiments. 


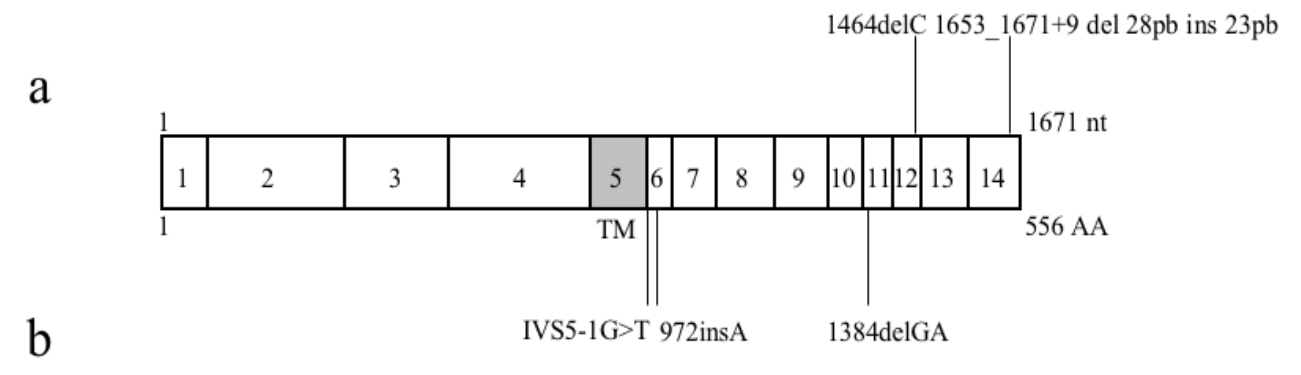

Kindred A

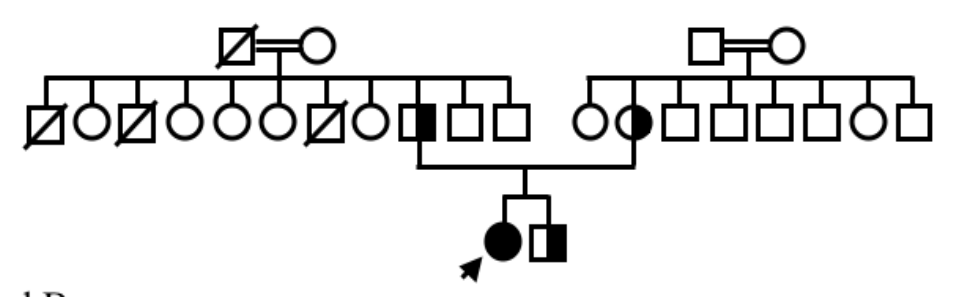

Kindred B

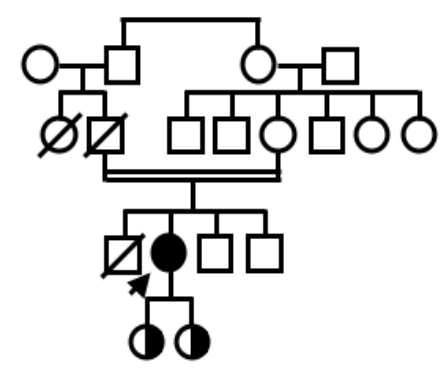

225

226 Figure 1 
Vince et al

a

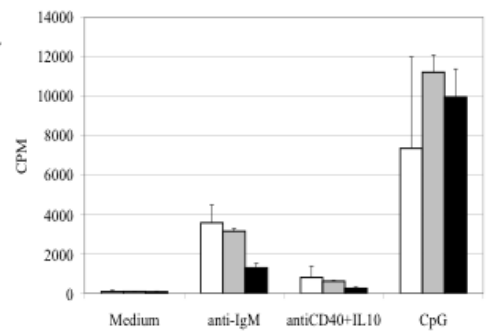

b
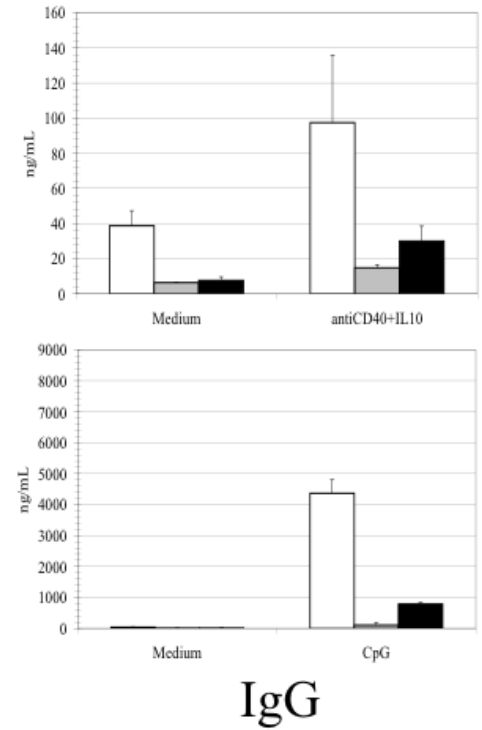

Control

Patient A

- Patient B
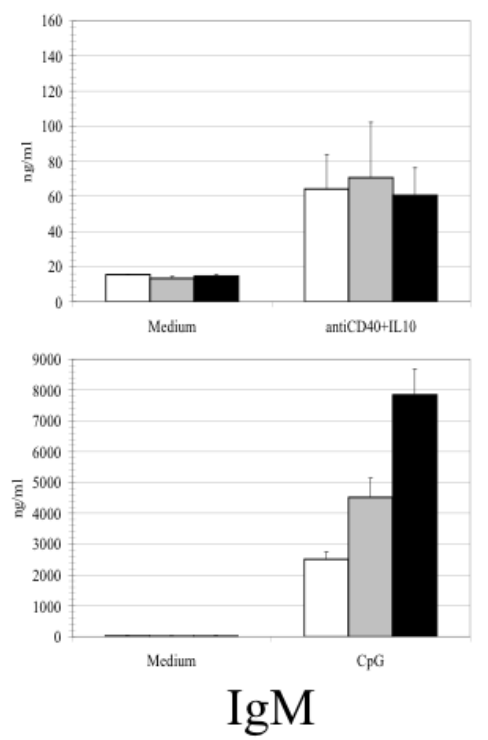